\title{
Review
}

\section{Among the New Books}

\author{
N. JAMES
}

\section{The environment}

Environmental archaeology (details below) considers the 'profound fracture ... between archaeologists dealing with the artefactual evidence and those engaged in the study of biological and geological remains' (p. 4). The editor opens by assessing several reasons for the division, including the distractions of 'post-processualism' and the organization of teaching in universities. There follow 13 very interesting discussions from various points of view, some addressing each other helpfully, including $S$. Roskams \& T. Saunders piling in with marxism against post-processualism, T. O'Connor exchanging with the offer of an anthropological approach from $Y$. Hamilakis, and G. Hughes, A. Hammon, R. Roseff and P. Graves-Brown on the situation of fieldwork for rural and urban development. Then there are seven sets of case studies (and commentaries) from around the world, including R. Shiel on 'using religious belief to derive environmental information'. G. Barker rounds off the proceedings with reflections on the issues. They are, indeed, very substantial; but they cannot be resolved without a clearer notion of what all the archaeology is for anyway. Dr Hamilakis was sniffing about in the right direction; but a yet broader view of the 'data' is needed. The solution could, indeed, come from university: archaeology needs to be taught as a science directed by anthropological agendas.

UMBERTO ALBARELLA (ed.). Environmental archaeology: meaning and purpose. $\mathrm{x}+324$ pages, 34 figures, 3 tables. 2001. Dordrecht: Kluwer Academic; 0-7923-6763-4 hardback $£ 80, € 118$ \& US $\$ 125$.

SING C. CHEW. World ecological degradation: accumulation, urbanization, and deforestation, 3000 $B C-A D 2000$. ix+217 pages, 12 figures, 4 tables. 2001. Walnut Creek (CA): Altamira; 0-7591-0030-6 hardback \$62, 0-7591-0031-4 paperback \$24.95.

Mr CHEw recounts how regions of the world have been undone in six ages: that of Mesopotamia and Harappa; that of the Minoans and Mycenaeans (described at some relative length) and then those of Classical Greece and (exploiters, he explains, but also restorers) the Romans; the turns of China and Southeast Asia and of western Europe, AD 500-1800; and then, 'Europe at the helm', during the last two centuries. He concludes with a chapter on 'ecologi- cal consciousness and social movements' since 2700 BC. Plenty of references are provided but - small wonder - the story is very compressed. Following the Mycenaean period, for instance, 'pottery styles became austere, unlike the decadent style of the prior era ... The lack of intense firing suggests ... dwindling energy supplies. As recovery proceeded ... we find the plain ... designs giving way to images depicting animals and humans' (p. 60).

DAVID W. WOLFE. Tales from the underground: $a$ natural history of subterranean life. xi+221 pages, 32 figures. 2001. Cambridge (MA): Perseus; 0-73820128-6 hardback $\$ 26$.

Every archaeologist - and everyone else - will enjoy Dr WOLFE's fascinating and very readable account of the life, the physics and the chemistry of soil and of the history of research and of human abuse. There are nearly a billion bacteria per gramme of earth near the surface of (temperate, presumably] soil! Congratulations to Perseus on such a thoroughly enlightening, well-designed and well-bound little book; and see their The dragon seekers ('Note too', below).

\section{Middle \& Near East}

RAINER MiCHAEL BoEHMER. Uruk: früheste Siegelabrollungen (Ausgrabungen in Uruk-Warka Endberichte 24). xii+319 pages, 159 figures, 2 tables. 1999. Mainz: Phillip von Zabern; 3-8053-19010 hardback DM198 \& $€ 101.24$.

Prof. BOEHMER reports on the earliest cylinder seals and sealings recovered in the great long-running German excavations at Uruk (Warka). First, the finds from the Eanna temple complex are described, in historical groups (Uruk V, IVb, IVa) with attention to contexts and to the respective pictorial themes. Then the finds from the Anu Ziggurat are described and, thirdly, those in the collection found west of the Riemchen Building. The seal identified as the earliest is unstratified. Prof. BOEHMER discusses the associations of the seals and sealings with other sites in greater Mesopotamia and beyond. Six indexes of the finds are provided. Large photographs and drawings are appended. The report has been produced to the most magnificent standards in every way.

HARRIET CRAWFORD. Early Dilmun seals from Saar: art and commerce in Bronze Age Bahrain. 111 pages, 
colour \& b\&w figures, 4 tables. 2001. Stoke St Milborough: Archaeology International; 0-95395610-5 hardback.

PAUL YUle \& GERD WEISGERBER. The metal hoard from 'Ibri/Selme, Sultanate of Oman (Prähistorische Bronzefunde 20:7). $x+160$ pages, 28 figures, 9 tables, 51 plates. 2001. Stuttgart: Franz Steiner; 3-51507153-9 hardback DM138.66 \& SFr119.40 \& Sch1014 $\& € 71$

The first publication from Robert Killick \& Jane Moon at Archaeology International is a most elegant and generously designed production on the early seals from their site on Bahrain. Dr CRAWFORD's classification and stylistic and functional analysis of the corpus and of the provenances is accompanied by a systematically annotated catalogue illustrated with colour photographs and analytic drawings. She remarks that the islanders drew on various cultural influences.

A hoard of bronze and stone vessels and bronze bangles, tools and weapons is reported by Drs YULE \& WEISGERBER. They are thought to date from the Early Iron Age and to have been looted from a cemetery in antiquity. That the bronze vessels were flattened out suggests that they were robbed in order to be melted down. The report is a painstaking description of the finds, including drawings, and of chemical analysis of samples of the bronzes. The hoard is of special importance for a region where archaeological research is only now finding its feet; many of the tools are of types not recorded before. The report has been produced to the usual impeccable standard of the Prähistorische Bronzefunde series.

MARC LEBEAU \& ANTOINE SUREMAN (ed.). Tell Beydar, three seasons of excavations (1992-1994): a preliminary report. (European Centre for Mesopotamian Studies.) 243 pages, plates, figures \& tables. 1997. Turnhout: Brepols; 2-503-50584-8 paperback BEF2200.

Messrs LEBEAU \& SULEIMAN introduce 19 detailed reports on stratigraphy, pottery and other finds from Tell Beydar, in northern Syria, which was occupied from the 'Ubaid period to the end of the 1st millennium BC. Most of the attention is devoted to the 3rd millennium and the late 1st. The articles are in French, English and German.

JEAn Bottéro with André Fine's, BERTRAND LAFONT \& GEORGES Roux (tr. Antonia Nevill). Everyday life in ancient Mesopotamia. xii+276 pages, 1 map. 2001. Edinburgh: Edinburgh University Press; 0-7486-1387-0 hardback \& 0-7486-1388-9 paperback $£ 45 \& £ 16.95$.

JEAN BOTTÉRo (tr. Teresa Lavender Fagan). Religion in ancient Mesopotamia. xiii+246 pages, 2 figures. 2001. Chicago: University of Chicago Press; 0-226-06717-3 hardback $\$ 30$ \& £19.

GWENDOLYN LEICK. Mesopotamia: the invention of the city. xxii +360 pages, 44 figures. 2001. London: Allen Lane; 0-713-99198-4 hardback £25.
Prof. BoTTÉRo's two books are intended for the general reader. The 15 agreeable introductory essays on Everyday life cover the origin of Sumer and the Royal cemetery at Ur, food, drink and cooking ( $c f$ Food in 'Romans', below), 'Love and sex in Babylon', women's life in the Akkadian period and the legend of Semiramis (see too the following pair of titles), healing, astrology, and trial by ordeal, and mythology. In his other book, Prof. BOTTÉRO discusses religion in general, the historical background in Mesopotamia, and the sources, before considering the concepts and devoting two long chapters to representation and mythology and to cults and rites. He goes on to consider Mesopotamian influences on later religions. Religion shares the first book's humane spirit but is more coherent, thanks to its focus. See too the following section.

\# The aptly subtitled invention of the city is a conceptually and academically rounded and most readable (and witty) introduction to the archaeology and histories of ten cities from Eridu to Nineveh and Babylon, including 'Akkad'. Full references (English, German, French, Italian) are provided in the endnotes. It is substantial yet manageable, a really satisfying book useful for teachers as well as the general reader.

ZAINAB BAHRANI. Women of Babylon: gender and representation in Mesopotamia. xii+212 pages, 44 figures. 2001. London: Routledge; 0-415-21830-6 hardback $£ 45$ \& $\$ 67.50$.

BETTY DE SHONG MEADOR. Inanna, lady of largest heart: poems of the high priestess, Enheduanna. $x i x+225$ pages, 23 figures. 2000. Austin (TX): University of Texas Press; 0-292-77692-6 hardback $£ 28.50$, 0-292-77693-4 paperback $£ 16.50$.

Dr BAHRANI's review is largely art historical but she is well grounded in the literature on Sumer and Assyria. It ranges broadly from Çatal Hüyük to the Hellenistic period. Postmodernist and feminist inspiration lead her to assess 'difference', 'metaphorics', and 'object of desire' before homing in on 'patronage, portraiture, identity'. She concludes on 'Ishtar ... embodiment of tropes' and on 'orientalist imagination' in 19th-century Europe. Ms MEADOR reads the poetry of Enheduanna of Ur as meditations on the potentials of femininity. The first part of the book sets the scene in the Akkadian period and the second is devoted to analysis of the poetry. Ms MEADOR suggests that Enheduanna 'records the birth of individual consciousness' (p. 79).

RICHARD P. HARPER \& DENYS PRINGLE with ANTHONY GREY \& ROBERT WILL. Belmont Castle: the excavation of a Crusader stronghold in the Kingdom of Jerusalem (British Academy Monograph in Archaeology 19). 261 pages, 81 figures, 60 plates. 2000 . Oxford: Oxford University Press; 0-19-727009-3 hardback £60.

Excavation documented the conversion of Belmont from a fortified manor of the early 12 th century to a 
castle a generation later. Seized and destroyed by the Saracens within 50 years, the site was later occupied by a village until 1948 . The core of the detailed, thorough and systematic report is the summary of the site's development; and it is accompanied by 10 sections on finds (including a long one on clay pipes of the 17th to 20th centuries). Prof. PRINGLE sums up and analyses the architectural sequence, and compares other castles in the region. The design is clear and helpful. The book has been finely produced. See also 'Franks and Crusaders' on pp. $\mathbf{X X X}$ and Carisbrooke Castle in 'Britain', below.

\section{Religion in Egypt}

JAN ASSMANN. The search for God in ancient Egypt (tr. David Lorton). xii +275 pages, 13 figures. 2001. Ithaca (NY): Cornell University Press; 0-8014-37865 hardback $£ 29.50$ \& $\$ 45,0-8014-8729-3$ paperback $£ 12.95$ \& $\$ 19.95$.

STEPHEN QUIRKE. The cult of Ra: sun-worship in ancient Egypt. 184 pages, 97 figures, 1 table. 2001. London: Thames \& Hudson; 0-500-05107-0 hardback 318.95 .

CHRISTIAN CANnuyer. Coptic Egypt: the Christians of the Nile (tr. Sophie Hawkes). 144 pages, colour \& b\&w illustrations. 2001. London: Thames \& Hudson; 0-500-30104-2 paperback $£ 6.95$.

What, for the ancient Egyptians, was the nature of the world's governing spirits? Was it intrinsic in the world or did 'the gods' operate in a distinct domain to be reached by worship? With the evidence of ancient texts, Prof. ASSMANN considers Egyptian theology, 'implicit' and 'explicit', polytheism, cosmology, and cults and rites. The last chapter assesses the conceptual innovations under Pharaoh Akhenaten. Plenty of texts are provided to illustrate the arguments. This deep, analytic book is of the greatest interest not only for specialists in matters Egyptian but also for comparative studies.

Writing firmly and lucidly for the more general reader, Dr QUIRKE addresses some of the same questions but with less concern for theology as such, and more for the role of kings. The principles of the Sun's cosmic work are explained by reference to myths, hymns (drawing on Prof. Assmann's research) and rites, and the monuments, especially the fragmentary remains of Iunu (Heliopolis). The last chapter discusses Akhenaten. The cult of Ra draws a great range of information together to demonstrate a coherent theme which provides a key to understanding much of ancient Egyptian thought. The emphasis on kingship is an effective conceptual 'handle' but Dr QUIRKE warns the reader that experience of and assumptions about the modern world are hindrances that have to be controlled for. Egypt's was 'a solar system different from our own and yet the same' (p. $16)$. This is a very satisfying book.

Coptic Egypt is another of the series of hectic little books translated from Gallimard's list. The book serves as a general introduction. Like several of the others in the series, the format is frustrating for so vivid and fascinating a subject. The pictorial treatment emphasizes the arts but the text does some justice too to the history. The heritage of ancient Egypt is assessed; and so, briefly, is the plight of the Copts today.

See also the review of The cosmos on p. 654, below.

\section{Aegean}

CAROLE GILLIS, CHRISTINA RISBERG \& BIRGITTA SJÖBERG (ed.). Trade and production in premonetary Greece - acquisition and distribution of raw materials and finished products: proceedings of the 6th international workshop, Athens 1996. 120 pages, 11 figures, 8 tables. 2000. Jonsered: Paul Åström; 91-7081-1962 paperback Kr250.

TRACEY CULLEN (ed.). Aegean prehistory: a review (American Journal of Archaeology Supplement 1). xvii+506 pages, 112 figures, 8 tables. 2001. Boston (MA): Archaeological Institute of America; 0-96090424-7 hardback \$59.95, 0-9609042-5-5 paperback $\$ 32.95$.

GILLIS et al. introduce five papers covering: Neolithic obsidian; Linear B evidence for 'Craft production at Knossos' and, more particularly, for textile production there, analogies from the Near \& Middle East for Bronze Age metallurgy, and Mycenaean lead. Dr CuLLEN introduces papers originally published as 'Review of Aegean prehistory' I-VII in the American Journal of Archaeology (1992-98), each now provided with an addendum.

CHRISTOPHER MEE \& ANTONY SPAWFORTH. Greece: an Oxford archaeological guide. xvi+464 pages, 182 figures, 1 table. 2001. Oxford: Oxford University Press; 0-19-288058-6 paperback £14.99.

FRANÇOIS HARTOG. Memoirs of Odysseus: frontier tales from ancient Greece (tr. Janet Lloyd). xiv+258 pages. 2001. Edinburgh: Edinburgh University Press; 0-7486-1448-6 hardback $£ 50,0-7486-1447-8$ paperback $£ 16.99$.

The latest of Oxford's new series of elegant guide books to reach us is Greece. It is very informative on generalities and background as well as specific features, including helpful guidance on 'getting there' and 'walking about'. Most of the plans are apt but some of the photographs poor. Dr HARTOG assesses the remarks and the conventions of voyagers and armchair travellers about the Aegean and central Mediterranean, Egypt and the Middle East from Homer to Herodotus to Polybius, Strabo and Apollonius of Tyana. Helpful background on these and all other matters of the history and formal culture is provided by the following title, now reissued.

JOHN BOARDMAN, JASPER GRIFFIN \& OSWYN MURRAY (ed.). The Oxford history of Greece and the Hellenistic world. viii+520 pages, 22 figures, tables. 2001. Oxford: Oxford University Press; 0-19-2801376 paperback £9.99. 


\section{Romans}

JON COULSTON \& HAZEL DODGE (ed.). Ancient Rome: the archaeology of the Eternal City (Oxford University School of Archaeology Monograph 54). xi+408 pages, 177 figures, 4 tables. 2000. Oxford: Oxford University School of Archaeology; 0-947816-55-0 paperback $£ 19.95$.

Ancient Rome is intended to review the extensive recent and continuing archaeological and topographic research in the city. It comprises 13 papers by British, Irish and US scholars. They cover: the city's early development and its late decay; the rhetoric of the monuments during the reign of Augustus; the army; the building industry; provisioning and water supply (D. Mattingly, G. Aldrete and H. DODGE); entertainment (see the previous title); 'houses and tombs' (J. Patterson); and religion. Aptly included is an essay on development following unification of Italy in 1870. Notes are provided too on 'sources for ... study' and there is a long Research Bibliography. This stimulating book will serve anglophone scholars usefully until the new round of more substantial publications eventually lumbers off the presses. Compare London in 'Britain', below.

ANN OLGA KolOSKI-OSTROW (ed.). Water use and hydraulics in the Roman city (Archaeological Institute of America Colloquia \& Conference Papers 3). $x i+131$ pages, 59 figures, 2 tables. 2001. Dubuque (IA): Kendall/Hunt; 0-7872-7690-1 paperback $\$ 46$.

Symbolism, geology and technology of Water for Roman cities and villas are covered in seven learned, very informative but concise chapters including both general reviews and case studies (on Pompeii two, Athens, Sicily, Africa). The authors conclude with broad but well defined recommendations for further empirical research. The photographs are poor.

John PEARCE, Martin MilletT \& MANUELA STRUCK (ed.). Burial, society and context in the Roman world. xxiv+272 pages, 175 figures, 12 tables. 2000. Oxford: Oxbow; 1-84217-034-1 paperback £35.

Dr PEARCE et al. present 27 empirical papers plus a general introduction (PEARCE), brief thematic introductions, and a critical 'afterword' by R. Reece. The papers are grouped: rites (including a paper on the Late Iron Age in north-west Europe); social status; topographic settings; ethnicity in Cologne and the danubian region; and a miscellany on the late period in Britain and Italy. Half of them are on the north-western provinces. Abstracts are provided in English, French and German.

ALISON FUTRELL. Blood in the arena: the spectacle of Roman power. xiii+338 pages, 36 figures, 9 tables. 2000. Austin (TX): University of Texas Press; 0-292-72523-X paperback $£ 17.95$

SimON KEAY \& Nicola TERrenato (ed.). Italy and the West: comparative issues in romanization. xiii +233 pages, 44 figures. 2001. Oxford: Oxbow; 1 84217-042-2 paperback $£ 24$.
GWYN DAVIES, ANDREW GARDNER \& KRIS LOCKYEAR (ed.). TRAC 2000: proceedings of the tenth annual Theoretical Roman Archaeology Conference, London, 2000. vi+168 pages , 36 figures, 11 tables. 2001. Oxford: Oxbow; 1-84217-043-0 paperback £18.

$\Rightarrow$ Blood in the arena, first published in 1997, is a fascinating study of amphitheatres. The thesis is familiar, that display of power was vital for integrating the Roman world; but what is so gratifying and exciting here is the well written analytic sweep across the literary and archaeological sources for both Rome and the provinces and also comparative studies from Carthage and Dahomey, Ur and Anyang, to the Aztecs (with whom more could have been made about the 'elite strategy' for acculturation). Dr FUTRELL puzzles over the distribution of the amphitheatres.

Italy and the West comprises eight papers and an introduction and conclusions on Italy, six and an introduction on the provinces, and two assessments of the proceedings, including S.E. Alcock (converging with J.P. Vallat's remarks about the papers on Italy) on Roman cultural 'hegemony', The coverage is refreshing: six Italians contribute on Italy; two papers on Spain, one on Leptis Magna, and one on diet (A. King). This sane collection is distinguished by alertness to the sociology of culture change - to who took part and who, perhaps, did not.

DAVIES et al. present two papers on museum presentation and one on historiography, seven on ancient symbolism (including $\mathrm{M}$. Aldhouse Green on iconography of antlers) and cultural identity (note G. Hawkes on 'foodways' at Dragonby), and three on cemeteries (including J. Pearce appraising L. Watts's proposition that Christian cemeteries include higher proportions of infants). The emphasis is mostly on Britain.

JOAN P. ALCOCK. Food in Roman Britain. 192 pages, 101 figures, 27 colour plates. 2001. Stroud \& Charleston (SC): Tempus; 0-7524-1924-2 paperback $£ 16.99$ \& $\$ 27.99$.

Following a short chapter on evidence, Dr ALCOCK assesses the varieties of food and drink and then describes kitchens and dining rooms. There is a chapter on shopping. She ends with two on diet and nutrition. This is a clear introduction but it does not do justice to the social anthropology of food ( $c f$ DAviES et al. and, in 'Middle East', above, Everyday Iife; and see BOUVIER in 'Note too', below).

WILliam ManNING. Roman Wales. $\mathrm{x}+129$ pages, figures, colour photographs. 2001. Cardiff: University of Wales Press \& Western Mail; 0-7083-1675-1 paperback $£ 6.99$.

Roman Wales describes itself as a guide book. It is compact but, otherwise, that description is misleading. It is a good, systematic review for the general reader of the history and archaeology.

GUY DE LA BÉDOYĖRE. Eagles over Britannia: the Roman army in Britain. 256 pages, 126 figures, 32 
colour plates. 2001. Stroud \& Charleston (SC): Tempus; 0-7524-193-4 hardback £25 \& US\$37.50.

Tony WilmotT. Birdoswald Roman fort: 1800 years on Hadrian's Wall. 191 pages, 89 figures, 26 colour plates. 2001. Stroud \& Charleston (SC): Tempus; 0-7524-1913-7 paperback £17.99 \& \$29.99.

Eagles is a comprehensive, systematic and detailed review of the province's military archaeology, covering its history and the principles of organization and recruitment. It shows both the integration of the armies in Britain with the Continental forces and the distinctively British features. There is less sense of Roman cultural strategy than in Burial, blood, Italy and the west, or TRAC 2000. Indeed, with an eye to the cash economy, Mr DE' LA BÉDOYÈRE suggests 'that the induction of Roman culture was a consequence of military action and colonisation' (p. 227). Even if so, he is wrong to cite the Spanish conquests of the Americas as another instance of military skill - disease was the conqueror there.

Birdoswald concentrates on the Roman archaeology but considers the fort's subsequent fate and adaptions of the fabric and the site into the Modern period, including archaeological research - a good idea carried out succinctly and effectively. 'Its story will continue' (p. 180). See too Plundering, in the next section.

See too GILLIVER in 'Paperback editions', below.

PAT SOUTHERn. Julius Caesar. 160 pages, 35 figures. 2001. Stroud \& Charleston (SC): Tempus; 07524-1443-7 hardback £17.99 \& \$29.99.

Ms SOUTHERN's thorough review of a familiar story is a thoughtful assessement of the man, an 'expert psychologist and manipulator' (p. 101). Her style is delightfully approachable: lean and lucid, witty and pacy; Caesar's shade must approve.

JEREMY KNIGHT. Roman France: an archaeological field guide. 224 pages, 55 figures. 2001. Stroud \& Charleston (SC): Tempus; 0-7524-1919-4 paperback $£ 17.99$ \& $\$ 29.99$.

Following an introduction to the history, architecture and rural archaeology, Roman France describes monuments in 13 regions. The sites are grouped sensibly by districts. The content is scholarly but, covering both history and field archaeology, the presentation is dense and the design uninviting, with surprisingly few plans.

DAVID CHERRY (ed.). The Roman world: a source book. $\mathrm{x}+268$ pages, 10 figures, 2 plates. 2001. Malden (MA) \& Oxford: Blackwell; 0-631-21783-5 hardback $£ 55$ \& $\$ 64.95,0-631-21784-3$ paperback $£ 15.99$ \& $\$ 29.95$.

The Roman world comprises 57 annotated excerpts from the XII Tables to Juvenal and the Theodosian Code, Plutarch to Anon. on family ethics, Columella et al. on the ecomony, Celsus et al. on science, Caesar, Tacitus, Cicero, Vegetius et al. on government, Rome, the army and the provinces, and selections from Apuleius to Eusebius on religious identities.

\section{Britain}

IAN FISHER. Early medieval sculpture in the west highlands \& islands. xiv +178 pages, figures. 2001. Edinburgh: Royal Commission on the Ancient and Historical Monuments of Scotland \& Society of Antiquaries of Scotland; 0-903903-30-X hardback $£ 20$.

Early medieval sculpture lists about $460 \mathrm{carv}-$ ings from the western highlands of Scotland, the islands of the Firth of Clyde, and the Hebrides (and all the way out to St Kilda and North Rona). It includes an abbreviated but up-dated version of the inventory of approximately 300 carved stones published earlier in the volumes on Argyllshire by the Royal Commission on the Ancient \& Historical Monuments of Scotland, and now adding eight new finds from that district. The gazetteers are annotated systematically and in great detail. The accompanying drawings and photographs are excellent, although some of the photographs of the landscape settings are poorly reproduced.

Most of the sculptures date from the early Christian period. They include 'Pictish' art and ogham inscriptions. The substantial introduction explains the institutional context and its history and assesses classification of the carvings, the chronology of them, iconography and cultural associations. It reviews the history of research and considers problems of preservation. Accompanying it are fine drawings to serve comparison.

Early medieval sculpture is Monograph 1 of a series to be produced jointly by the Antiquaries of Scotland and the Royal Commission. Up to the best of old fashioned standards, it augurs very well for more.

C.J. Young. Excavations at Carisbrooke Castle, Isle of Wight, 1921-1996 (Wessex Archaeology Report no. 18). xii+231 pages, 68 figures, 36 tables, 55 plates. 2000. Salisbury: Wessex Archaeology; 1 874350-27-2 (ISSN 0965-5778) paperback $£ 21.50$.

The report on Carisbrooke Castle shows that it was built in two phases during the Norman period, took most of its present form in the 13th century, and remained in use up to the Stuart period. The site was first used as a cemetery in the Saxon period. The report reveals the topographic development of the defences. The finds of iron included many fragments of military equipment. Although the castle was associated with aristocrats, the pottery assemblages recovered were modest; and that has provided a view of the Isle's own culture. The report has been produced to a high standard. It is provided with summaries in French, German and Spanish. See too Belmont Castle in 'Middle East', above, 'Franks and Crusaders' on pp. 635-9, below, and the review of Hen Domen on p. 650. 
IAN HAYNES, HARVEY SHELDON \& LESLEY HANNIGAN (ed.). London under ground: the archaeology of a city. vii +327 pages, 75 figure, 6 tables. 2000. Oxford: Oxbow; 1-84217-030-9 hardback $£ 35$.

London under ground appraises technical and conceptual results of research in connection with redevelopment in and immediately around the capital between 1972 and 1997. Messrs SHELDON \& HAYNES introduce 15 papers covering historical periods, localities, and substantive and methodological themes. An appendix lists excavations, publications and notable events. Replete with long bibliographies, this book is a technical work but it is an effective and timely reminder of the public value of investment in the archaeology of the city and the landscapes which it has covered. Compare Ancient Rome in 'Romans', above.

ALAN ABERG \& CARENZA LEwIS (ed.). The rising tide; archaeology and coastal landscapes. iv +122 pages, 60 figures, 4 tables. 2000. Oxford: Oxbow; 1 84217-028-7 paperback £25.

FRANCIS PRYOR. Seahenge: new discoveries in prehistoric Britain. xxviii+337 pages, 28 figures, 1 table, 50 b\&w photographs. 2001. London: Harper Collins; 0-00-710191-0 hardback £19.99.

ABERG \& LEWIS introduce seven topical reports on work along coasts in England, three on Scotland, one on Strangford Lough, one on Saxony, and one on work by the National Trust. The reports are diverse but succinct and generally well illustrated. The editors argue that 'regional cooperation' between the various organizations concerned is 'the only logical approach' (p. 3). They point out that public interest in the recent discovery of 'Seahenge' shows how important it is to monitor changing shores. Seahenge is a personable account, for the general reader, by one of the archaeologists most closely involved, of the fraught and very controversial process of investigation there. Along the way, he takes the opportunity to explain a lot about British prehistory and the nature of archaeological investigation. He remarks caustically on 'mystical memory and emotional osmosis' (p. 316) but points out that archaeologists must take account of lay interest. His book shows one way to do that.

C.R. WICKHAM-JONES. The landscape of Scotland: a hidden history. 255 pages, figures, 33 colour plates. 2001. Stroud \& Charleston (SC): Tempus; 0-75241484-4 paperback $£ 16.99 \& \$ 27.99$.

ThOMAS ReEs \& CORAlie Mills. Bracken and archaeology (Technical Advice Note 17). vi +36 pages, 27 figures, 2 tables. 1999. Edinburgh: Historic Scotland; 1-900168-618 paperback $£ 5$ plus p\&p £1.25.

Another and innovative method is Ms WICKHAMJONES' short and very effectively illustrated descriptions of scores of sites from Mesolithic middens to Roman roads, industrial sites, and the German fleet at Scapa Flow. She presents seven themes from farming to ritual. She also explains the work of the Scottish National Monuments Record and why it is that we are concerned to manage archaeological resources. Its title notwithstanding, the book gives the impression that sites are the critical units. For professional practitioners, Bracken and archaeology recommends principles of management that 'could equally be applied to all environmental factors' (p. 30). Full of well-illustrated practical advice, it is systematic, succinct and clearly presented.

$\notin$ TIM EATON. Plundering the past:Roman stonework in Medieval Britain. 160 pages, 77 figures, 25 colour plates. 2000. Stroud \& Charleston (SC): Tempus; 0-7524-1903-X paperback $£ 15.99 \& \$ 27.50$.

That Roman masonry and sculpture was robbed and recycled during the earlier Middle Ages is a truism of the trade well worth systematic reassessment and Dr EATON has now taken the study of this phenomenon further than predecessors. His investigation is methodical and attractively presented. Distinguishing between contexts, he attempts to amplify and refine the work of D. Stocker on why Roman stone was re-used. He suggests that, among other purposes, 'archaism' (to borrow a term from elsewhere) was characteristic of the mid and perhaps later Saxon period. He has considered buildings from various regions but also presents case studies (Chepstow, Hexham). It would be valuable to compare France or the Rhineland.

FRAN \& GEOFF DOEL. The Green Man in Britain. 162 pages, 80 illustrations. 2001. Stroud \& Charleston (SC): Tempus; 0-7524-1916-1 paperback $£ 12.99$ \& $\$ 22.50$.

Beating back the sceptics with the help of a gazetteer of nearly 1000 carvings in stone or wood (almost all in England), Mr \& Mrs DOEL hold that the folklore of the Green Man can be traced back to the Middle Ages. Many of the gazetteer's entries are too simple (e.g. 'bench end', pp. 150-51).

N.J. HIGHAM \& D.H. HILL (ed.). Edward the Elder, 899-924. xvi+320 pages, 45 figures, 10 tables. 2001. London: Routledge; 0-415-21496-3 hardback $£ 55$ \& $\$ 82.50,0-415-21497-1$ paperback $£ 16.99$ \& $\$ 25.49$.

Dr HIGHAM introduces and rounds up 20 scholarly assessments of aspects of King Edward's reign. They dwell on administration, politics and strategy with plenty of attention to archaeology (note J. Graham-Campbell on northern hoards), architecture (C. Heighway on the minster at Gloucester), and historical topography (D. HILL on Mercian shire towns) as well as art history and history. Papers on the north (including R. Hall on York) and Ireland (A. Woolf) add perspective.

Ð J $\Lambda$ MES DYER. Discovering prehistoric England: a gazetteer of prehistoric sites (2nd edition). 248 pages, figures. 2001. Princes Risborough: Shire; 0-7478-05075 paperback $£ 9.99$. 


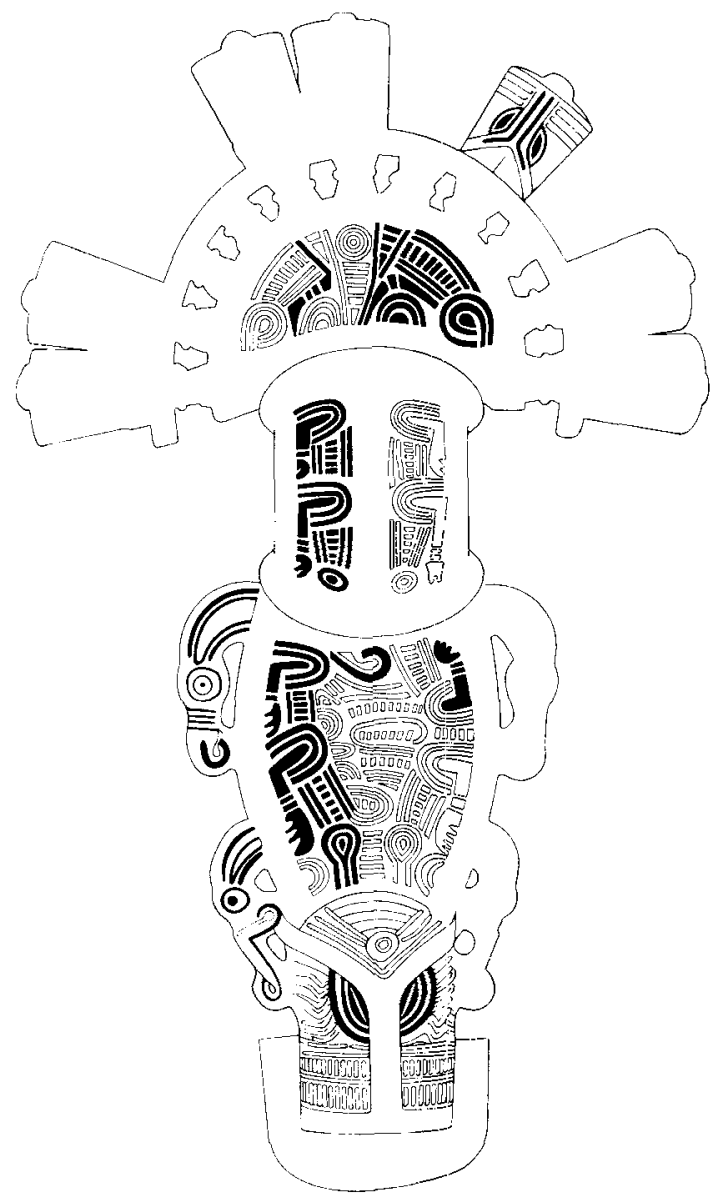

The analysis of a gilt and niello silver bow brooch illustrates Lidia Paroli's contribution to KATHARINE REYNOLDS BROWN, DAFYDD KIDD \& CHARLES T. LITTLE (ed.) From Attila to Charlemagne: arts of the early Medieval period in the Metropolitan Museum of Art (xxxiv+395 pages, 407 figures, 18 colour plates, 1 bEw plate. 2001. New York (NY): Metropolitan Museum of Art; 0-300-08894-9 paperback £36). The brooch is $157 \mathrm{~mm}$ long. It is Langobardic, c. $A D$ 600. Dr Paroli found 'animal art' all over the brooch. The 25 other contributions to the same very well produced book describe and assess the art history of other pieces in the Metropolitan Museum's collection, notably jewellery. There are a couple of notes on the collector, J.P. Morgan, and on the archaeological background; but, needless to say, the assessment of context of the finds and the collection is thin and uncritical.
Mr DYER's very compendious, highly detailed and exceedingly learned gazetteer has been redesigned, up-dated and expanded.

See also 'Romans', above.

\section{South Asia}

R.S. SHARMA. Early Medieval Indian society: a study in feudalisation. $x+374$ pages, 12 tables. 2001. London: Sangam; 0-86311-845-3 hardback £29.95.

MANUEL KEENE with SALAM KAOUKII. Treasury of the world: jewelled arts of India in the age of the Mughals. 160 pages, 291 colour figures, $1 \mathrm{~b} \& \mathrm{w}$ figure. 2001. London: Thames \& Hudson; 0-500-976082 paperback $£ 18.95$.

Prof. SHARMA's coherent approach is steeped in marxism: 'what distinguished the period was continuous feudalisation. . . The sultans themselves became victims' of it (p. 284). Ideology notwithstanding, the process was not always smooth, he points out. A compact appendix reviews 'material culture' - astronomy, metallurgy (especially iron working), brickwork (Nalanda), medicine, water management, etc.

Treasury of the world is a sumptuous catalogue for the recent exhibition at the British Museum. Like Attila to Charlemagne (see our picture review), it betrays scarcely a hint of the struggles of the time.

\section{The seas}

MICHAEL MCCARTHY. Iron and steamship archaeology: success and failure on the SS Xantho. xiv+234 pages, 77 figures. 2000. New York (NY): Kluwer Academic/Plenum; 0-306-46365-2 hardback \$59.

ROBERT S. WEDDLE. The wreck of the Belle, the ruin of La Salle. xvii+327 pages, 20 figures. 2001. College Station (TX): Texas A\&M. University Press; 1-58544-121-X hardback $\$ 29.95$.

P.J. CAPELOTTI. Sea drift: rafting adventures in the wake of 'Kon-tiki'. xxi+295 pages, 23 figures. 2001. New Brunswick (NJ): Rutgers University Press; 08135-2978-6 hardback \$26.

The SS Xantho was wrecked off Western Australia in 1872. Mr MCCARTHY assesses the ship with data from archives (finding that it was an inappropriate vessel for the undeveloped conditions of that coast at the time) and explains in detail the procedures and results of recording and excavation. Special attention is paid to the physical and chemical processes of 'site formation'. Parts of the wreckage were taken to a laboratory for treatment and investigation. Discrepancies were found between the finds and the archives; and MCCARTHY takes issue with K. Muckleroy's dictum that we do not need archaeology of documented ships. The book is distinguished by commentary on methods. Pagination in the contents pages is awry.

In 1995, the wreck of La Salle's last ship was found along the Texas coast. Mr WEDDLE explains for the general reader how it was lost, in 1685, during the explorer's attempts to establish a French presence in the region. 
Sea drift is an absorbing account for the general reader. It has been written and produced pleasantly and elegantly.

\section{Note too}

MiCHEL BOUvIER. Les saveurs du vin antique: vins d'hier, vignerons d'aujourd'hui. 200 pages, b\&w figures. 2001. Paris: Errance; 2-87772-209-X paperback F160 \& $€ 24.39$.

CHRISTOPHER MCGOWAN. The dragon seekers: how an extraordinary circle of fossilists discovered the dinosaurs and paved the way for Darwin. $\mathrm{xvi}+254$ pages, figures. 2001. Cambridge (MA): Perseus; 07382-0282-7 hardback \$26 \& CAN\$39.50.

\section{Paperback editions}

LEONARD BARKAN. Unearthing the past: archaeology and aesthetics in the making of Renaissance culture. xxxiv +428 pages, 199 figures. 1999. New Haven (CT): Yale University Press; 0-300-07677-0 hardback $\$ 40,0-300-08911-2$ paperback $\$ 19.95$.

C.M. GILLIVER. The Roman art of war. 192 pages, 57 figures. 2001. Stroud \& Charleston (SC): Tempus; 0-7524-1939-0 paperback $£ 15.99$ \& \$26.99.

TADHG O'KeEFFE. Medieval Ireland: an archaeology. 192 pages, 77 figures, 25 colour plates. 2001. Stroud \& Charleston (SC): Tempus; 0-7524-1926-9 paperback $£ 15.99 \& \$ 26.99$.
These titles were reviewed in ANTIQUITY 74: 435, 715-16 and 957, respectively.

\section{Also received - European}

VÍtor Oliveira Jorge (ed.). Proto-histórico de Península ibérica $\left(3^{\circ}\right.$ Congresso de arqueologia peninsular, UTAD, Vila Real, Portugal, Setembro de 1999, uma organizaçao ADECAP-UTAD: Actas [Vol. 5]). 541 pages, figures, tables. 2000. Oporto: ADECAP; 972-97613-7-X paperback.

HANS BOLIN, ANDERS KALIFF \& TORUN ZACHRISSON (ed.). Mellan sten och brons: uppdragsarkeologi och forskning kring senneolitikum och bronsålder (Occasional Papers in Archaeology 27, Stockholm Archaeological Reports 39). 152 pages, 35 figures. 2001. Uppsala: Uppsala University Institute of Archaeology \& Ancient History; 91-631-0623-X paperback.

FRÉDÉRIC DELOUCHE (ed.). Illustrated history of Europe: a unique portrait of Europe's common history (2nd edition). 416 pages, colour \& b\&w illustrations. 2001. London: Cassell; 1-84188-108-2 paperback $£ 18.99$.

\section{Fiction}

PAUL DOHERTY. The house of death: a mystery of Alexander the Great. xii +276 pages, 1 map. 2001. London: Constable; 1-84119-302-X hardback £16.99.

\section{Review articles}

\section{Interpreting the Neolithic of western Asia}

\section{KATHERINE I. WRIGHT*}

JACQUES CAUVIN. The birth of the gods and the origins of agriculture (tr. Trevor Watkins). xviii +259 pages, 70 figures, 8 plates. 2000 . Cambridge: Cambridge University Press; 0-521-651352 hardback $£ 37.50$ \& US\$59.95.

IAN KUIJT (ed.). Life in Neolithic farming communities: social organization, identity, and differentiation.

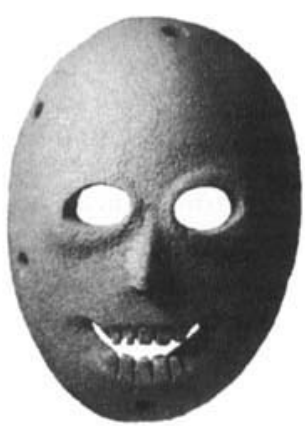
xvi+325 pages, 44 figures, 10 tables. 2000. New York (NY): Kluwer Academic/Plenum; 0-306-46122-6 hardback $\$ 80$.
Western Asia has an extraordinarily rich record of the emergence of agriculture and village life. Recent fieldwork has revealed a degree of social complexity once thought to be confined to only a few sites (e.g. Jericho, Catalhöyük). New finds of statues, paintings, monumental stelae, public buildings, human and animal burials, and even cemeteries now make it abundantly clear that, across western Asia, Neolithic villages had elaborate social structures and complex ideologies.

The wealth of new evidence has made it possible to push consideration of these matters forward and to transmit some of these findings to a wider readership. Ian Kuijt's Life in Neolithic farming communities is an important step in this direction, bringing together interpretations advanced by American,

* Institute of Archaeology, University College London, 31-34 Gordon Square, London wc1H 0pY, England.

ANTIQUTYY 75 (2001): 619-21 